\title{
EDUKASI PADA PENGAWAS MINUM OBAT DAN PASIEN DIABET MILLITUS TIPE 2 UNTUK MENINGKATKAN KEPATUHAN MINUM OBAT
}

\section{EDUCATION MODEL ON DRUG SUPERVISOR AND TYPE 2 DIABETES MELLITUS PATIENT TO IMPROVE DRUG COMPLIANCE}

\author{
Daniek Viviandhari*, Nora Wulandari \\ Fakultas Farmasi dan Sains, Universitas Muhammadiyah Prof. Dr. Hamka \\ "Penulis Korespondensi, e-mail: daniek.viviandhari@uhamka.ac.id
}

\begin{abstract}
ABSTRAK
Permasalahan utama pasien DM adalah kepatuhan dalam minum obat mengingat DM merupakan penyakit kronis yang membutuhkan terapi jangka panjang. Ketidakpatuhan dalam manajemen terapi DM dapat meningkatkan biaya pengobatan dan perawatan. Penelitian bertujuan untuk mengukur efektivitas model edukasi pada PMO (Pengawas Minum Obat) dan pasien DM tipe 2 dalam meningkatkan kepatuhan minum obat pada pasien DM tipe 2 di RSI (Rumah Sakit Islam) Pondok Kopi. Metode penelitian yang dipakai adalah penelitian eksperimental dengan rancangan quasi experimental - pretest/post-test study design yang dilakukan secara prospektif. Intervensi yang diberikan adalah edukasi berupa ceramah dan pembagian booklet yang diberikan sebanyak 3 kali selama 2 bulan periode penelitian. Uji statistik yang digunakan adalah paired-sample $t$ test dengan CI 95\% untuk melihat perbedaan kadar HbA1c sebelum dan setelah pemberian intervensi. Perbandingan kepatuhan pasien berdasarkan skor kuesioner MMAS-8 dilakukan dengan uji Wilcoxon. Nilai HbA1C pasien sebelum intervensi ratarata 7,2 dan setelah edukasi nilai HbA1c rata-rata sebesar 5,5 $(\mathrm{P}<0,05)$. Skor MMAS-8 pada awalnya rata-rata 4,4 menjadi rata-rata 2,4 setelah diberikan intervensi berupa edukasi $(\mathrm{P}<0,05)$. Kesimpulan penelitian ini adalah model edukasi pada PMO dan pasien DM tipe 2 di Rumah Sakit Islam Jakarta Pondok Kopi efektif untuk meningkatkan kepatuhan pasien dengan menurukan nilai HbA1c dan skor MMAS-8.
\end{abstract}

Kata kunci : kepatuhan, edukasi, DM tipe 2, PMO

\section{ABSTRACT}

The main problem of DM patients is medication adherence considering DM is a chronic disease that requires long-term therapy. Noncompliance in DM therapy management may increase the cost of treatment and care. The objective of the study was to measure the effectiveness of education model in drug supervisor and type 2 DM patients in improving drug adherence in patients with type 2 DM in Rumah Sakit Islam Pondok Kopi. The research method used was experimental research with experimental quasi design - pre-test / post-test study design conducted prospectively. Intervention given was education in the form of general lectures and booklet handouts, was given 3 times during the 2 months of the study period. The statistical test used was paired-sample $t$ 
test with $95 \%$ CI to measure the difference of HbAlc levels before and after intervention. Comparison of patient compliance based on MMAS-8 questionnaire scores was done by Wilcoxon test. The HbAlC value of the patients before the intervention averaged 7.2 and after intervention the average HbAlc value is 5.5 ( $P$ $<0.05)$. MMAS-8 scores initially averaged 4.4 to an average of 2.4 after being given educational intervention $(P<0.05)$. The conclusion of this research is the education on drug supervisor and type 2 DM patient at Rumah Sakit Islam Jakarta Pondok Kopi effective to improve patient compliance by decreasing HbAlc value and MMAS-8 score.

Keywords : medication adherence, education, type 2 DM, drug supervisor

\section{PENDAHULUAN}

Diabetes melitus (DM) merupakan penyakit gangguan metabolik menahun akibat pankreas tidak dapat memproduksi cukup insulin atau tubuh tidak dapat menggunakan insulin yang diproduksi secara efektif. Akibatnya terjadi peningkatan konsentrasi glukosa di dalam darah (hiperglikemia) dan perubahan metabolisme lemak dan protein. Jika tidak ditangggulangi dengan baik maka gangguan metabolisme ini dapat menyebabkan komplikasi mikrovaskular dan makrovaskular yang akan meningkatkan biaya pengobatan pasien (Koda-Kimble et al., 2009).

DM merupakan masalah kesehatan dunia yang secara global, prevalensinya diestimastikan 6,4\%, mempengaruhi 285 juta orang dewasa pada tahun 2010 dan diproyeksikan meningkat sampai 7,7\%, 439 juta orang dewasa pada tahun 2030. Diperkirakan antara 2010 dan 2030, akan ada peningkatan 69\% jumlah orang dewasa dengan diabetes di negara-negara berkembang dan meningkat 20\% di negara-negara maju (Shaw et al., 2010). Data dari IDF (2015) menunjukkan prevalensi DM pada orang dewasa (20-79 tahun) di Indonesia adalah 6,2\%. Prevalensi tertinggi DM yang terdiagnosa oleh dokter terdapat di daerah DI Yogyakarta $(2,6 \%)$ dan DKI Jakarta (2,5\%) (Balitbangkes, 2013).

DM merupakan penyakit dengan pengobatan yang kompleks, yang membutuhkan perawatan medis yang terus menerus. Pengobatan DM membutuhkan waktu yang lama, tidak menyenangkan dan seringkali menyulitkan pasien dikarenakan regimen pengelolaannya yang mencakup berbagai aspek. Selain itu pasien DM perlu melakukan perubahan perilaku secara terus menerus agar pengobatan menjadi efektif (Smalls et al., 
2012), sehingga kepatuhan pasien menjadi salah satu faktor yang berperan penting dalam pengobatan pasien DM.

Kepatuhan pengobatan didefinisikan sebagai sejauh mana perilaku penggunaan obat seseorang bertepatan dengan nasihat medis atau kesehatan (Cramer et al., 2008). Kepatuhan pasien terhadap pengobatan DM masih sangat rendah. Dari sebuah penelitian yang dilakukan Perez et al., (2013) kurang dari 50\% pasien yang mencapai keberhasilan terapi, di mana hal ini juga mengindikasikan masih rendahnya kepatuhan pasien DM tipe 2.

Edukasi dan dukungan pengelolaan mandiri pada pasien DM sangat penting untuk mencegah komplikasi akut dan risiko komplikasi jangka panjang dan terdapat bukti yang signifikan bahwa dukungan dalam berbagai intervensi meningkatkan hasil perbaikan pada diabetes (ADA, 2016). Edukasi terhadap pasien DM beserta keluarganya mutlak diperlukan untuk mengatasi ketidakpatuhan karena DM adalah penyakit yang berhubungan dengan gaya hidup (Soegondo et al., 2011). Pada suatu penelitian, program edukasi juga diketahui efektif dalam memperbaiki HbAlc, gula darah puasa, kolesterol, BMI, trigliserida (Rashed et al., 2016). Berbagai metode intervensi apoteker secara signifikan memperbaiki pengontrolan glukosa darah penderita DM dengan penurunan kadar $\mathrm{HbA1c}$, antara lain pemberian intervensi apoteker berupa konseling disertai penyajian booklet dan atau kotak obat, serta dengan berdiskusi tentang pengobatan, pill count, edukasi tentang perubahan gaya hidup dan diet serta pemberian pamphlet diabetes (Collins et al., 2011; Puspitasari, 2012; Yuniarti, 2013).

Program edukasi terhadap pasien diabetes telah banyak dilakukan di Indonesia. Program edukasi yang sudah ada adalah pemberian edukasi yang dilakukan langsung kepada pasien. Kenyataanya, pasien diabetes sendiri banyak dialami oleh pasien yang berusia lansia dengan tingkat pemahaman yang rendah. Pengobatan yang lama juga terkadang membuat pasien bosan dan lupa untuk mengkonsumsi obat yang mengakibatkan penurunan kepatuhan sehingga menyebabkan gula darah pasien tidak terkontrol. Oleh karena itu untuk mengantisipasi hal tersebut peneliti merasa perlu ada pengawasan pada pasien DM saat melakukan pengobatannya dengan membentuk PMO seperti yang dilakukan pada pengobatan TB (Tubercullosis). Di Indonesia istilah PMO 
lebih diperuntukkan pada seorang pengawas minum obat pada pasien TB. Pada penelitian ini, diharapkan diperoleh efektifitas dari model edukasi yang diberikan tidak hanya diberikan kepada pasien DM tipe 2 tersebut tetapi juga kepada PMO-nya. Penelitian ini bertujuan untuk mengukur efektivitas model edukasi pada PMO dan pasien DM tipe 2 dalam meningkatkan kepatuhan minum obat pada pasien DM tipe 2 di RSI (Rumah Sakit Islam) Pondok Kopi.

\section{METODE PENELITIAN}

\section{Desain Penelitian}

Penelitian yang dilakukan adalah penelitian eksperimental dengan rancangan quasi experimental - pre-test/post-test study design yang dilakukan secara prospektif. Populasi penelitian ini adalah semua pasien DM tipe 2 rawat jalan yang berobat di RSI Pondok Kopi selama periode penelitian. Sampel penelitian ini adalah seluruh pasien DM tipe 2 yang berobat di RSI Pondok Kopi selama periode penelitian yang memenuhui kriteria inklusi dan kriteri eksklusi berikut:

1. Kriteria Inklusi:

Kriteria inklusi sampel dari penelitian ini adalah :
a. Pasien DM tipe 2 yang sedang tidak hamil berusia $>18$ tahun
b. Memiliki diabetes lebih dari 1 tahun
c. Dapat berbahasa dan mengerti Bahasa Indonesia
d. Pasien yang mendapat obat anti diabetes
e. Pasien dengan kadar glukosa darah puasa $>126 \mathrm{mg} / \mathrm{dl}$
f. Pasien yang datang berkala ke rumah sakit untuk pemeriksaan rutin
g. Pasien memiliki keluarga satu rumah yang dapat dijadikan PMO (berusia 18- 50 tahun dan berpendidikan minimal SMA)

\section{Kriteria Ekslusi}

Kriteria ekslusi sampel dari penelitian ini adalah :

a. Pasien berusia $>18$ tahun tetapi tidak dapat menjawab kuisioner secara mandiri dikarenakan memiliki penyakit mental, pikun, atau komorbiditas lainnya, kondisi medis yang tidak stabil seperti pasien rawat inap. 
b. Pasien dengan masalah pendengaran dan atau penglihatan

c. Wanita hamil dengan diabetes atau terdiagnosa diabetes gestasional

Data diambil secara prospektif dari sumber data pasien rawat jalan Rumah Sakit Islam Pondok Kopi Jakarta Timur. Intervensi diberikan kepada pasien DM tipe 2 dan PMO yang bersedia menjadi responden. Intervensi yang diberikan adalah edukasi berupa ceramah dan pembagian booklet. Intervensi diberikan sebanyak 3 kali selama 2 bulan periode penelitian. Pasien yang memenuhi kriteria inklusi dan bersedia menjadi responden penelitian di follow up setelah 2 bulan. Data yang dikumpulkan merupakan pretest dan postest berupa hasil pemeriksaan $\mathrm{HbA}_{1 \mathrm{c}}$ dan wawancara menggunakan kuesioner MMAS-8 untuk menilai kepatuhan. Penelitian ini mengukur efektifitas antara variabel bebas (independent) yakni intervensi edukasi berupa ceramah dan booklet pada pasien DM tipe 2 dan PMO terhadap skor kuesioner MMAS-8 dan nilai $\mathrm{HbA}_{1 \mathrm{c}}$ sebagai variabel terikat (dependent).

\section{Jalannya Penelitian}

Protokol penelitian yang telah disetujui, diajukan kepada pihak rumah sakit untuk dilakukan review oleh komite etik RSI Pondok Kopi untuk mendapatkan izin penelitian dan kepada Komite Etik Badan Penelitian dan Pengembangan Kesehatan Kementerian Kesehatan. Skrining pasien dilakukan setelah izin penelitian didapatkan. Pasien diminta kesediaannya untuk ikut serta sebagai responden penelitian dengan menandatangani surat persetujuan partisipasi atau inform consent dan diberi informasi terlebih dahulu. Tahap pengumpulan data :

1. Subjek yang telah bersedia menjadi responden mengisi formulir ketersediaan mengikuti penelitian. Sample size minimal tidak ditentukan. Metode sampling yang digunakan adalah total sampling, yaitu semua responden yang bersedia mengikuti jalannya keseluruhan penelitian dan memenuhi kriteria inklusi.

2. Melakukan pretest dengan menggunakan kuesioner MMAS-8 dan pengukuran kadar $\mathrm{HbA}_{1 \mathrm{C}}$. Peneliti tidak melakukan pengukuran pengetahuan dan perilaku pasien atau PMO sebelum perlakuan. 
3. Responden diberikan edukasi berupa ceramah dan pembagian booklet sebanyak 3 kali dalam 2 bulan periode penelitian.

Ceramah dilakukan oleh peneliti sebanyak 2 orang yang merupakan dosen Fakultas Farmasi dan Sains UHAMKA. Pihak yang diberi ceramah dan materi booklet adalah pasien dan PMO. Ceramah disampaikan selama kurang lebih 1 jam, lalu dilakukan tanya jawab selama kurang lebih 1 jam. Edukasi dilakukan di salah satu ruangan di rumah sakit. Materi yang disampaikan terbagi menjadi 3 bagian : bagian pertama yaitu penjelasan umum terkait DM, komplikasi DM, dan terapi DM (termasuk jika pasien lupa minum obat). Bagian kedua yaitu pengaturan pola makan dan pengulangan penjelasan terapi DM. Bagian ketiga yaitu pengaturan latihan fisik (olah raga) dan pengulangan penjelasan terapi DM. Materi booklet terpisah menjadi 3 bagian dengan materi yang sama seperti yang disampaikan saat ceramah. Secara teknis, pasien dan PMO dikumpulkan dalam suatu ruangan di rumah sakit, lalu diberikan edukasi berupa ceramah dan booklet, dan di akhir sesi dilakukan tanya jawab (diskusi).

4. Melakukan posttest setelah 2 bulan penelitian dengan menggunakan kuesioner MMAS-8 dan pengukuran kembali kadar $\mathrm{HbA}_{1 \mathrm{C}}$.

5. Data yang diperoleh kemudian direkapitulasi untuk dilakukan pengolahan dan analisis data.

\section{Analisis Data}

Semua analisis statistik dilakukan menggunakan Statistical Package for Social Sciences software for Windows versi 22.0 (SPSS Inc., Chicago, USA) menggunakan uji paired t-test.

\section{HASIL DAN PEMBAHASAN}

Penelitian pendahuluan telah dilakukan di dua Puskesmas di daerah Jakarta Timur pada bulan September 2016 s/d Januari 2017. Penelitian pendahuluan ini dilakukan dengan model yang berbeda yakni dengan hanya mengintervensi subyek penelitian (pasien DM) saja. Pada penelitian pendahuluan ini didapatkan hasil peningkatan 
kepatuhan yang signifikan yang dilihat dari penurunan kadar HbA1c dan Skor MMAS8. Hasil penelitian pendahuluan ini telah dipublikasikan dalam oral presentasi pada The 17th Asian Conference on Clinical Pharmacy (ACCP) pada tanggal 27-30 Juli 2017 yang lalu dan telah lolos untuk dipublikasikan dalam proceeding internasional dengan Nomor ISBN 9781138081727.

Dengan dasar penelitian pendahuluan tersebut dilakukan penelitian serupa tetapi dengan intervensi yang berbeda pada pasien di RSIJ Pondok Kopi. Intervensi yang diberikan tidak hanya diberikan kepada pasien saja tetapi juga dengan PMO dari keluarga terdekat pasien tersebut. Selama periode penelitian dari bulan Mei 2017 s/d Oktober 2017 didapatkan sejumlah 28 responden. Alur pengumpulan responden penelitian ditampilkan dalam Gambar 1.

Data yang terkumpul selama periode September 2016 s/d Januari 2017 adalah sebanyak 42 sampel pasien, yang terdiri dari:

- 25 pasien Wanita

- 17 Pasien Laki-laki

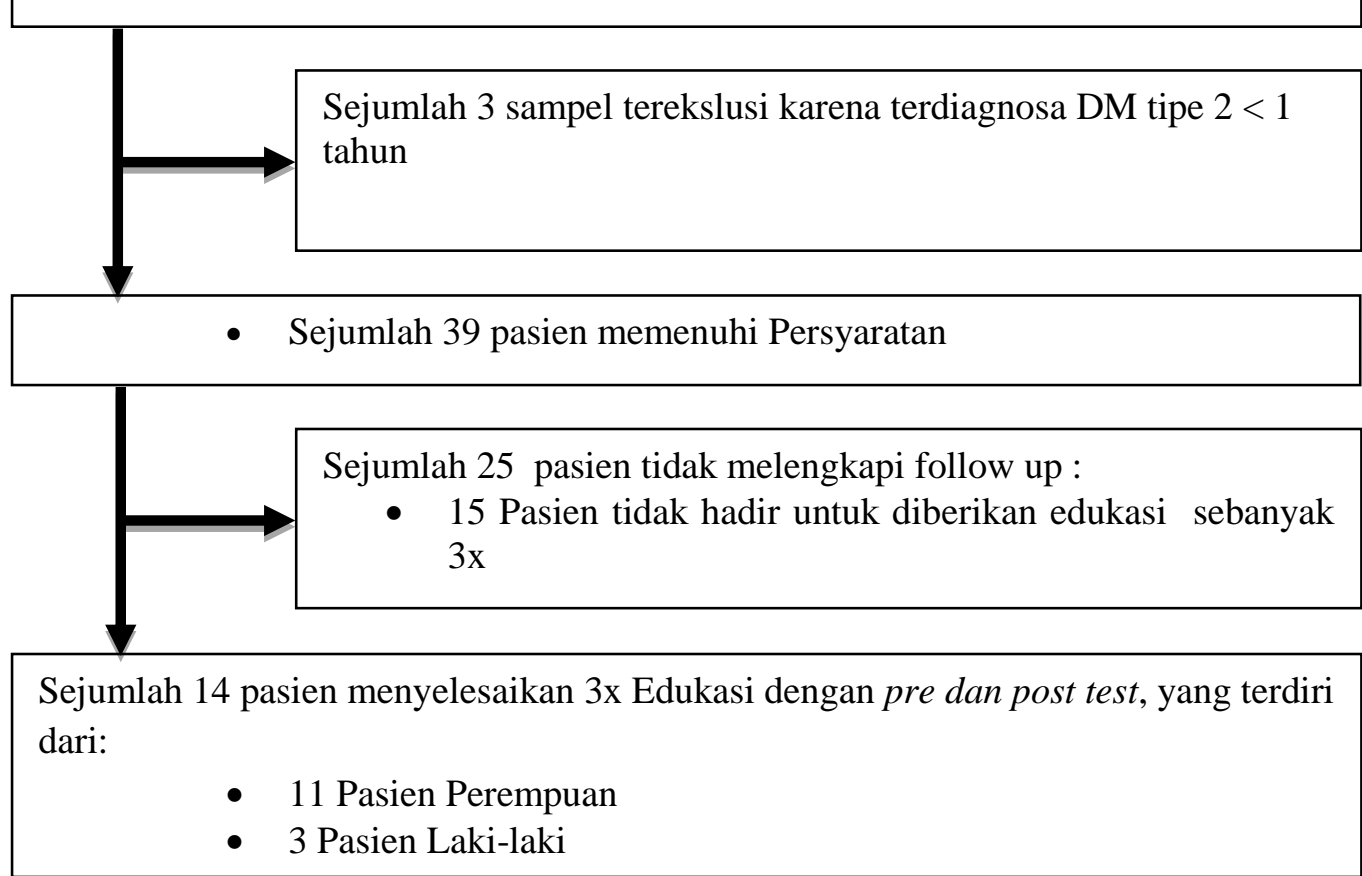

Gambar 1. Alur pendapatan sampel penelitian 


\section{Gambaran pasien DM tipe 2 di RSIJ Pondok Kopi}

a. Karakteristik sosio-demografi

Karakteristik sosio-demografi responden yang dikumpulkan dalam penelitian ini adalah jenis kelamin, usia, tingkat pendidikan dan pekerjaan. yag ditampilkan pada Tabel I. Karakteristik sosio-demografi responden berdasarkan jenis kelamin menunjukkan bahwa sebagian besar responden, yaitu 78,6\% berjenis kelamin wanita. Dari penelitian pendahuluan yang dilakukan $73,3 \%$ pasien juga berjenis kelamin perempuan (Wulandari et al., 2017). Penelitian serupa yang dilakukan oleh Yuniarti (2013) dan Presetiawati (2013) menunjukkan hasil yang sama dengan prevalensi penderita DM tipe 2 lebih besar dari pada perempuan.

Tabel I. Karakteristik sosio demografi

\begin{tabular}{llc}
\multicolumn{1}{c}{ Karakteristik } & \multicolumn{1}{c}{ Nilai } & SD \\
\hline Jenis Kelamin & & .42582 \\
Laki-laki, $n(\%)$ & $3(21,4)$ & \\
Perempuan, $n(\%)$ & $11(78,6)$ & \\
Total, $(\%)$ & $14(100,0)$ & \\
\hline Usia & & .51887 \\
$<60$ tahun, $n(\%)$ & $7(50,0)$ & \\
$\geq 60$ tahun, $n(\%)$ & $7(50,0)$ & \\
Total, $(\%)$ & $14(100,0)$ & \\
\hline Tingkat pendidikan & & .82542 \\
Rendah, $n(\%)$ & $3(21,4)$ & \\
Menengah, $n(\%)$ & $4(28,6)$ & \\
Tinggi, $n(\%)$ & $7(50,0)$ & \\
Total, $(\%)$ & $14(100,0)$ & \\
\hline Pekerjaan & & \\
Tidak bekerja, $n(\%)$ & $13(92,9)$ & \\
Bekerja, $n(\%)$ & $1(7,1)$ & \\
Total, $(\%)$ & $14(100,0)$ & \\
\hline
\end{tabular}

Responden yang termasuk dalam kriteria penerimaan penelitian ini adalah pasien DM tipe 2 yang berobat ke RSI Pondok Kopi dengan rentang usia di atas 18 tahun. Pemilihan rentang usia didasarkan pada pertimbangan bahwa sesuai dengan pendataan yang dilakukan oleh Kemenkes bagi penyakit degeneratif dimulai sejak usia 18 tahun (Balitbangkes 2013). Sebagian responden (50\%) memiliki usia lansia yakni $\geq 60$ tahun, dan sebagian lainnya berusia dewasa.

Gambaran sosio-demografi responden berdasarkan status pekerjaan menunjukkan 92,9\% tidak bekerja. Hal ini dikarenakan sebagian besar responden adalah 
wanita yang merupakan ibu rumah tangga dan sebagian lainnya adalah pensiunan karena umur responden berkisar lebih atau sama dengan 60 tahun atau berada dalam kelompok usia lansia.

Tingkat pendidikan responden pada penelitian ini bervariasi dari rendah hingga tinggi. Sebanyak masing-masing 50\% responden memiliki tingkat pendidikan tinggi dan sisanya $28,6 \%$ dan $21,3 \%$ masing-masing berpendidikan menengah dan rendah. Hasil ini agak sedikit berbeda dengan responden yang didapatkan pada penelitian pendahuluan yang rata-rata berpendidikan menengah dan rendah. Hal ini dapat dikarenakan sampel yang digunakan berasal dari sumber yang berbeda yakni rumah sakit dan puskesmas.

b. Karakteristik klinik

Gambaran karakteristik klinik responden ditampilkan pada Tabel II. Responden yang telah mengalami DM tipe 2 selama $\geq 5$ tahun sebesar $57,1 \%$ dan $42,9 \%$ responden dengan penyakit penyerta, terutama hipertensi. Prevalensi penderita DM yang mengalami hipertensi tergantung pada tipe diabetes, umur, obesitas dan etnik.

Tabel II. Karakteristik klinik

\begin{tabular}{lcc}
\hline \multicolumn{1}{c}{ Karakteristik } & Nilai & SD \\
\hline Durasi DM & & .51355 \\
<5 Tahun, $n(\%)$ & $6(42,9)$ & \\
$\geq 5$ Tahun, $n(\%)$ & $8(57,1)$ & \\
Total, $n(\%)$ & $14(100,0)$ & .51887 \\
\hline Penyakit Penyerta & & \\
$\quad$ Tidak Ada, $n(\%)$ & $7(50,0)$ & \\
Ada, $n(\%)$ & $14(100,0)$ & \\
Total, $n(\%)$ & & \\
\hline Jenis Obat DM & $8(57,4)$ & \\
1 Jenis, $n(\%)$ & $2(14,3)$ & \\
2 Jenis, $n(\%)$ & $3(21,4)$ & .05090 \\
3 Jenis, $n(\%)$ & $1(7,1)$ & \\
4 Jenis, $n(\%)$ & $14(100,0)$ & \\
Total, $n(\%)$ & & \\
\hline Efek Samping & $13(96,5)$ & \\
Tidak mengalami, $n(\%)$ & $1(3,5)$ & \\
Mengalami, $n(\%)$ & $14(100,0)$ & \\
Total, $n(\%)$ & & \\
\hline Penggunaan Obat Lain & $7(50,0)$ & \\
Ada, $n(\%)$ & $7(50,0)$ & \\
Tidak, $n(\%)$ & $14(100,0)$ & \\
Total, $n(\%)$ & & \\
&
\end{tabular}


Hipertensi adalah faktor risiko utama baik untuk penyakit kardiovaskular maupun komplikasi mikrovaskular (American Diabetes Association, 2016). Responden berjumlah 57,4\% mendapatkan 1 jenis obat antidiabetes dengan yaitu golongan biguanid (metformin). Sebanyak masing-masing 14,3\% dan 21,4\% mendapat antidiabetes oral sebanyak 2 jenis dan 3 jenis, dan 7,1\% responden menerima antidiabetes oral dalam kombinasi 4 obat. Perhimpunan Endokrinologi Indonesia (2011) menganjurkan penggunaan kombinasi 2 hingga 3 jenis ADO apabila monoterapi tidak dapat menstabilkan kadar glukosa darah setelah 2-3 bulan (pengukuran kadar HbA1c > $7 \%)$.

Sebanyak 1 orang responden pernah mengalami efek samping seperti lemas, pusing dan gemetar setelah menggunakan glibenklamid. Lemas dan gemetar adalah gejala hipoglikemia yang dapat terjadi setelah menggunakan antidiabetes golongan sulfonilurea seperti glibenklamid tanpa disertai asupan kalori yang cukup atau setelah melakukan aktifitas fisik yang berat (Lacy et al,. 2009). Gejala hipoglikemia biasanya terjadi ketika kadar glukosa darah kurang dari 60 mg/dl, penanganannya dengan minum air bergula (teh manis, sirup dan lain-lain) tetapi bukan dengan pemanis buatan, lalu makan nasi seperti lazimnya (Soegondo et al., 2011).

\section{Karakteristik gaya hidup}

Gambaran karakteristik gaya hidup (lifestyle) responden sebelum dilakukan edukasi ditampilkan pada Tabel III. Sebanyak 85,7\% responden menyatakan melakukan pengaturan pola makan dengan pembatasan gula dan karbohidrat (nasi) serta 78,6\% responden menyatakan melakukan olahraga dan tidak ada satu orang pun yang mengaku memiliki kebiasaan dan riwayat merokok. Penekanan tujuan terapi gizi medis pada DM tipe 2 hendaknya pada pengendalian glukosa, lipid dan hipertensi. Penurunan berat badan dan diet hipokalori (pada pasien yang gemuk) dapat memperbaiki kadar glukosa darah jangka pendek dan mempunyai potensi meningkatkan kontrol metabolik jangka panjang. Perencanaan makan hendaknya dengan kandungan zat gizi yang cukup dan disertai pengurangan total lemak terutama lemak jenuh (Soegondo et al., 2011). Beberapa studi menunjukkan peran pola pengaturan makan (diet) terhadap penyakit kardiovaskular, inflamasi serta sindrom metabolik. Pada studi yang dilaksanakan oleh 
Health, Aging and Body Composition (Health ABC) menunjukkan bahwa mengkonsumsi banyak makanan yang rendah lemak, buah, gandum, unggas, ikan dan sayuran dihubungkan dengan penurunan kadar interleukin (IL-6). Berdasarkan aktifitas fisik, dalam "The Canadian Diabetes Association (CDA) 2003 Clinical Practice Guidelines" merekomendasikan penderita DM tipe 2 melakukan aktifitas fisik dengan intensitas sedang seperti berjalan cepat dan bersepeda sekurangnya 150 menit setiap minggu, minimal 3 hari secara tidak berurutan (Plotnikoff, 2004).

Tabel III. Karakteristik pola hidup

\begin{tabular}{ll}
\hline \multicolumn{1}{c}{ Karakteristik } & \multicolumn{1}{c}{ Nilai } \\
\hline Pola Makan & \\
Tidak Melakukan, $n(\%)$ & $2(14,3)$ \\
Melakukan, $n(\%)$ & $12(85,7)$ \\
Total, $n(\%)$ & $14(100,0)$ \\
\hline Merokok & $14(100,0)$ \\
Tidak Melakukan, $n(\%)$ & $0(0)$ \\
Melakukan, $n(\%)$ & $14(100,0)$ \\
Total, $n(\%)$ & \\
Olah Raga & $3(21,4)$ \\
Tidak Melakukan, $n(\%)$ & $11(78,6)$ \\
Melakukan, $n(\%)$ & $14(100)$ \\
Total, $n(\%)$ & $12(85,7)$ \\
\hline Obat Herbal & $2(14,3)$ \\
Tidak Menggunakan, $n(\%)$ & $14(100,0)$ \\
Menggunakan, $n(\%)$ & \\
Total, $n(\%)$ & \\
\hline
\end{tabular}

Responden yang menggunakan obat herbal sebanyak 14,3\%. Obat herbal yang digunakan responden seperti daun insulin, daun salam, daun sambiloto dan kulit manggis yang mereka yakini dapat membantu mengontrol kadar gula darah. Responden menggunakan tanaman tersebut dengan dengan cara direbus dengan air dan meminum hasil rebusan tersebut sebagai obat. Lebih dari 400 tanaman yang berbeda dan ekstrak tanaman diyakini bermanfaat bagi pasien diabetes. Sebagian besar tanaman ini telah dinyatakan memiliki sifat hipoglikemik tetapi sebagian besar pernyataan itu hanya perkiraan dan hanya sebagian kecil saja yang telah dilakukan pengujian secara medis dan ilmiah. Belum ada bukti yang cukup untuk menggambarkan kesimpulan yang pasti mengenai efikasi tanaman obat terhadap penderita diabetes (Yeh et al., 2003).

Namun data yang didapatkan pada karakteristik gaya hidup ini hanya berupa data subyektif yang kurang dapat dibuktikan kebenarannya, sehingga kurang representatif 
untuk diuji peningkatan perbaikannya dalam penelitian ini. Akan tetapi data ini dapat dijadikan referensi untuk ditunjukkan pada pasien yang memiliki tingkat kepatuhan yang rendah yang tunjukkan dengan nilai $\mathrm{HbA1c}$, sehingga pasien tersebut dapat memperbaiki gaya hidupnya.

c. Perbandingan kepatuhan pasien DM tipe 2 yang diberikan intervensi bersama dengan PMO berdasarkan penurunan kadar HbA1c dan skor MMAS-8

Berdasarkan uji statistik dengan uji t untuk sampel yang berpasangan (pairedsample t test) dengan CI 95\% dilakukan untuk melihat perbedaan kadar HbA1c sebelum dan setelah pemberian intervensi. Adapun untuk perbandingan kepatuhan pasien berdasarkan skor kuesioner MMAS-8 dilakukan dengan uji Wilcoxon. Perbandingan kepatuhan responden berdasarkan nilai rata-rata dan standar deviasi kadar HbA1c dan skor MMAS-8 sebelum dan setelah diberikan intervensi bersama dengan PMO ditampilkan pada Tabel IV.

Tabel IV. Perbedaan rata-rata kadar HbA1c dan Skor MMAS-8 sebelum dan setelah intervensi

\begin{tabular}{|c|c|c|c|}
\hline Variabel & Sebelum Intervensi & Setelah Intervensi & $P$ \\
\hline Rata-rata HbA1c \pm SD & $7,2- \pm 2,3$ & $5,5 \pm 1,1$ & 0,03 \\
\hline Rata-rata MMAS-8 \pm SD & $4,4 \pm 1,2$ & $2,4 \pm 1,3$ & 0,005 \\
\hline
\end{tabular}

Berdasarkan Tabel IV, rata-rata nilai HbA1C pasien 7,2 dan setelah diberikan intervensi berupa edukasi kepada pasien dan PMO-nya terjadi peningkatan kepatuhan yang ditunjukkan dengan rata-rata nilai HbA1c sebesar 5,5. Penurunan yang didapatkan pada kadar HbA1c pada penelitian ini lebih besar jika dibandingkan dengan penelitian sebelumnya yang berupa rata-rata 7,72 sebelum intervensi dan 6,18 setelah intervensi (Wulandari et al., 2017).

Hal serupa ditunjukkan oleh nilai skor MMAS-8 pada awalnya rata-rata 4,4 menjadi rata-rata 2,4 setelah diberikan intervensi berupa edukasi yang tidak hanya diberikan pada pasien tetapi juga dengan PMO-nya. Hal ini diperkuat dengan nilai $\mathrm{P}<0,05$ yang menunjukkan adanya perbedaan yang signifikan baik pada nilai kadar HbA1c maupun skor MMAS-8.

Keterbatasan penelitian ini adalah bahwa peneliti tidak dapat memastikan bahwa perubahan kadar HbA1c hanya karena faktor kepatuhan saja, namun terdapat faktor 
perancu lain yaitu terkait demografi dan lifestyle. Faktor perancu ini tidak peneliti nilai korelasinya dengan nilai HbA1c secara statistik.

PMO membantu mengingatkan dan memandu pasien (dalam hal ini adalah keluarganya) untuk patuh minum obat. Perubahan perilaku PMO tidak diamati karena fokus utama adalah pada pasien, jadi yang dinilai hanya pasien saja. Perilaku PMO termasuk variabel yang tidak dinilai.

\section{KESIMPULAN}

Model edukasi pada pengawas minum obat (PMO) dan pasien DM tipe 2 di Rumah Sakit Islam Jakarta Pondok Kopi efektif untuk meningkatkan kepatuhan pasien dengan menurunkan nilai HbA1c dan skor MMAS-8.

\section{UCAPAN TERIMAKASIH}

Penulis berterima kasih kepada DIKTI yang telah mendanai penelitian ini dan pihak RSI Pondok Kopi yang telah memberikan izin penelitian.

\section{DAFTAR PUSTAKA}

Alfian R., 2015, Korelasi Antara Kepatuhan Minum Obat dengan Kadar Gula Darah pada Pasien Diabetes Melitus Rawat Jalan di RSUD Dr. H. Moch. Ansari Saleh Banjarmasin, Jurnal Pharmascience, Vol 2, No. 2, Oktober 2015, hal: 15 - 23.

ADA, 2016, American Diabetes Association's "Standar of Medical Care in Diabetes2016". Diabetes Care; 39(suppl 1). Diakses tanggal 20 April 2016.

Antoine, S.L., Pieper, D., Mathes, T., Eikermann, M., 2014, Improving the adherence of type 2 diabetes mellitus patients with pharmacy care: a systematic review of randomized controlled trials, BMC Endocrine Disorders, DOI: 10.1186/14726823-14-53.

Balitbangkes, 2013, Riset Kesehatan Dasar 2013. Jakarta.

Collins, C, Limone, B.L., Scholle, J.M., Coleman, C.I., 2011, Effect of pharmacist intervention on glycemic control in diabetes. Diaetes Res Clin Pract;92:145-152.

Cowie, C.C., et al., 2006, Prevalence of diabetes and impaired fasting glucose in adults in the U.S., Diabetes Care;29:1263. 
Cramer, J., Roy, A., Burrell, A., Anuja, R., Burrell, A., Fairchild, C., Fuldeore, M., Ollendorf, D., Wong, P., 2008, Medication compliance and persistence. Terminology and definitions. Value Health;11: 44-47.

Hartono, Bambang, 2010, Promosi kesehatan di Puskesmas dan rumah sakit. Rineka Cipta.

IDF., 2015, Diabetes in Indonesia-2015. Diakses di http://www.idf.org/membership/wp/indonesia,

Koda-Kimble, M.A., Young, L.Y., Alldredge,B.K., Corelli, R.L., Guglielmo, B.J., Kradjan, W.A., Williams, B.R., 2009, Applied Therapeutics: the Clinical Use of Drugs Ninth Edition. Philadelphia: Lippincott Williams and Wilkins, P.50-3.

Kurniawan, I., 2010, Diabetes melitus type 2 pada usia lanjut, Majalah Kedokteran Indonesia; 60(12), 576-584.

Lacy, C.F., Armstrong, L.L., Goldman, M.P., Lance, L.L., 2009, Drug Information Handbook, $17^{\text {th }}$ edition, American Pharmacist Association.

Morisky, D.E., DiMatteo, M.R., 2011, The morisky 8-item self-report measure of mediacation-taking behavior (MMAS-8). Journal of Clinical Epidemiology; 64: 262-263.

Morisky, D.E., Munter, P., 2009, New medication adherence scale versus pharmacy fill rates in senior with hipertention. American Jurnal Of Managed Care, 15(1): 5966.

Notoatmodjo, S., 2010, Promosi kesehatan Teori dan Aplikasi. Jakarta : Rineka Cipta, Jakarta.

Osterberg L, Blaschke T., 2005, Adherence to medication. N Engl J Med; 353(5), 487491.

Perkeni., 2011, Konsensus Pengelolaan Dan Pencegahan DM tipe 2 di Indonesia 2011. Jakarta: Perkumpulan Endokrinologi Indonesia.

Perez, L.E.G., Alvarez, M., Dilla, T., Guilen, V.G., dan Beltran, D.O., 2013, Adherence to Therapies in Patients with Type 2 Diabetes, Diabetes Ther. ; 4(2): 175-194.

Plotnikoff, R.C., 2004, Physical Activity in the Management of Diabetes : Populationbased Perspectives and Strategies, Canadian Journal of Diabetes.

Prasetiawati, A.R., 2013, Hubungan Pengetahuan dengan Kepatuhan Penggunaan Terapi Insulin pada Pasien Diabetes Melitus Tipe 2 di Wilayah Kerja Puskesmas Krueng Barona Jaya Aceh Besar Tahun 2013, Skripsi, Kementrian Pendidikan dan Kebudayaan Universitas Syiah Kuala. 
Puspitasari, A,W., 2012, Analisis Efektifitas Pemberian Booklet Obat terhadap Tingkat Kepatuhan Ditinjaun dari Kadar Hemoglobin terglikasi (HbA1C) dan Morisky Medication Adherence Scale (MMAS)-8 pada pasien DM tipe 2 di Puskesmas Bakti Jaya Kota Depok. Tesis. Universitas Indonesia, Depok.

Rashed, O.A., Al Sabbah, H., Younis, M.Z., Kisa, A., \& Parkash, J., 2016, Diabetes Education Program for People with Type 2 Diabetes: An International Perspective. Evaluation and Program Planning;56: 64-68.

Sharma, T., Kalra, J., Dhasarna, D.C., Basera, H., 2014, Poor adherence to treatment: A major challenge in diabetes, JIACM ; 15(1): 26-9.

Shaw, J.E., Sicree, R.A., Zimmet, P.Z., 2010, Global estimates of prevalence of diabetes for 2010 and 2030. Diabetes Research and Clinical Practice; 87: 4-14.

Sloan, F.A., Bethel, M.A., Ruiz, D.Jr., Shea, A.M., Feinglos, M.N, 2008, The growing burden of diabetes mellitus in the U.S. elderly population. Arch Intern Med;168:192.

Smalls, B.L., Walker, R.J., Hernandez-Tejada, M.A., Campbell, J.A., Davis, K.S., Egede, L.E, 2012, Associations between coping, diabetes knowledge, medication adherence and self-care behaviors in adults with type 2 diabetes. General Hospital Psychiatry 34 (2012) 385-389.

Soegondo, S. Soewondo, P. Subekti, I (Editor), 2013, Penatalaksanaan Diabetes Melitus Terpadu. Jakarta: FKUI.

Tan X, Patel I, Chang J, 2014, Review of the four item Morisky Medication Adherence Scale (MMAS-4) and eight item Morisky Medication Adherence Scale (MMAS8). INNOVATIONS in pharmacy. Vol. 5, No. 3, Article 165.

Wulandari N, Viviandhari D, Nurhayati, 2017, A Strategic Approach to Increase the Compliance of Patients with Type 2 Diabetes Mellitus, in Unity in Diversity and the Standardisation of Clinical Pharmacy Services: Proceedings of the 17th Asian Conference on Clinical Pharmacy (ACCP 2017), July 28-30, 2017, Yogyakarta, Indonesia.

Yeh, G.Y., Eisenberg, D.M., Kaptchuk, T.J., Phillips, R.S., 2003, Systematic review of herbs and dietary supplements for glycemic control in diabetes, Diabetes Care Apr,26 (4): 1277-94.

Yuniarti, D, 2013, Evaluasi Kepatuhan Pasien DM Tipe 2 melalui Booklet yang disusun bersama Pasien di Puskesmas Beji dan Pancoran Mas. Universitas Indonesia, Jakarta. 